\title{
A SAFETY FEATURE FOR ANAESTHETIC MACHINES - TOUCH IDENTIFICATION OF OXYGEN FLOW CONTROL*
}

\author{
R. K. Calverley, m.D. $\nmid$
}

The ANAESTHETIST depends upon the safety features of anaesthetic machines to assist him in protecting his patient from danger. Some hazards, such as incorrect gas supply, have been significantly reduced by the development of colour-coded cylinders and the adoption of the Pin Index and Diameter Index Safety Systems.

Despite these and other safety devices, dangers still exist. One remaining potential hazard is that of improper gas selection. At present there is no standardization of flowmeter arrangement or design. As a result anaesthetists are in constant danger of turning up the wrong gas. If inadequate concentrations of anaesthetic agents are administered, the patient may awaken to experience pain and psychological distress. Should the oxygen supply be reduced excessively, a catastrophe may follow. Many experienced anaesthetists remember episodes in which patients have been exposed to inadequate oxygen concentrations due to incorrect identification of the gas control. This problem has occurred most frequently during resuscitation or during anaesthesia with unfamiliar apparatus.

Both of these potentially hazardous situations deserve special emphasis:

1. Resuscitation: When responding to an emergency, the anaesthetist is obliged to monitor and assess physical signs, as well as prescribe and apply appropriate therapy with great dispatch. When resuscitation is commenced during surgery, all anaesthetic agents are discontinued and oxygen alone provided. While preoccupied with other decisions, the anaesthetist may not pause to read the labels on gas controls and may inadvertently administer the wrong gas. This error jeopardizes the opportunity for recovery.

2. Position of oxygen rotameter: The anaesthetist must identify the location of each flowmeter on each machine he employs. The position of oxygen may be on the extreme left or right side of the rotameter panel or anywhere else, depending on the individual manufacturer's design. There is a need to standardize its position as hypoxia has been precipitated by broken cyclopropane rotameters.,

To diminish this danger E. I. Eger and his associates ${ }^{3}$ recommended that the oxygen rotameter should be placed nearest the outlet from the common collecting chamber to lessen the risk of oxygen leakage from a damaged upstream rotameter (Figure 1).

In 1968 David Katz recognized downstream leakage of oxygen in a Draeger anaesthesia machine caused by a defective screw. ${ }^{4}$ In a subsequent article ${ }^{5}$ he reported the manufacturer's objection to Eger's proposal. The objection is germane to this discussion.

From: The Department of Anaesthesia, The Hospital for Sick Children, Toronto, Canada.

łAddress: Department of Anaesthesia, Vancouver General Hospital, Vancouver 9, British Columbia, Canada. 

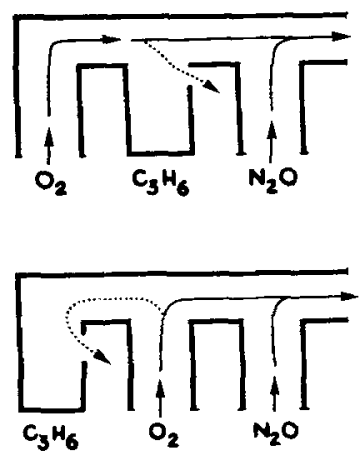

POTENTIALLY DANGEROUS
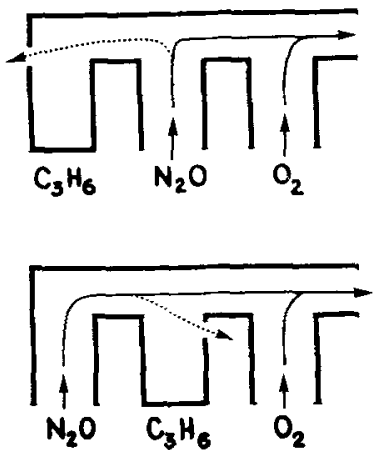

SAFE POSITION FOR OXYGEN

FIGURE 1. Diagram of flowmeter arrangements showing potential hazards. ${ }^{3}$

The company stated it would be easy to interchange the oxygen and nitrous oxide outlets in the flowmeter unit but this would introduce a new danger. Thousands of anaesthetists habitually reach to the left to operate the oxygen needle valve, and to the right to operate the nitrous oxide valve, sometimes without looking at the rotameter head. Interchanging the connections could only increase the danger of error.

Admittedly the attitude of the anaesthetist is important when considering alterations of equipment. Katz observed that individual preferences will always remain so it is important to distinguish the origin of these preferences. If they are merely habit, they can be changed, especially if the change removes a hazard. He concluded that despite the company's objection, the change should be made.

To reduce the danger of equipment failure, the oxygen flowmeter must always enter at the distal end of the flowmeter panel. An increasing number of manufacturers are currently modifying their anaesthetic machines to conform to Eger's recommendation.

When old machines are modified or new machines purchased, the change may lead to errors. The oxygen flowmeter knobs can be inexpensively modified, however, so that during the transition period and thereafter it can be readily identified by touch.

We have developed and clinically tested a knob of distinctive shape for controlling oxygen flow in any anaesthetic machine. While colour coding and labels provide visual identification of gas selection, the unique surface of this modified oxygen flow control guarantees tactile confirmation of choice.

\section{Preliminary Planning}

A number of factors were considered in preparing for this modification. These included:

1. Changes should be simple. Modification of all flow controls for all gases appeared to be unnecessarily complex. Although there may be as many as six 
gases on the rotameter panel, only oxygen supply is of paramount importance, therefore, the oxygen flow control was altered.

2. Did modifications already exist? The Foregger Company had developed touch identification of all controls, but used a round knob for the oxygen meter. As other manufacturers provided round knobs for all gases, the Foregger modification for oxygen was not unique and further modification was necessary.

3. Several types of machinery may be employed in a single hospital. Valve spindles vary remarkably in diameter and length so it would be impossible to cast a single universally adaptable knob for control of oxygen.

4. Changes should be incxpensive. The demand for substitute knobs would be limited and their production costly so existing knobs should be modified. The change should be simple so that it could be made quickly to avoid interrupting operating room schedules.

\section{MEthod}

A number of control knob designs were tested for ease of touch recognition and for ease of operation by the members of the Department of Anaesthesia of The Hospital for Sick Children, Toronto. Half of the staff reported that they could not discriminate with confidence between octagonal, hexagonal and round knobs of small diameter; many found that square or flanged knobs were difficult to manipulate rapidly.

The majority preferred a knob with projecting spokes around the circumference. The anaesthetists then carried out further touch trials on "spoked" varieties to determine the optimal number of spokes and the distance the spokes should project beyond the circumference.

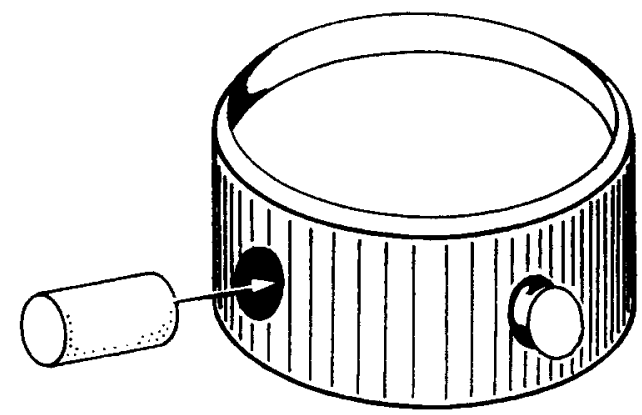

Figune 2. Construction diagram of modified oxygen flowmeter knob.

The knobs were prepared in the Prosthetic Shop of the Hospital's Orthopaedic Department. Holes of $1 \frac{1}{8}$-inch diameter were drilled into plastic or nickel-plated brass oxygen knobs from the anaesthetic machines (Figure 2). Nickel-plated brass rivets ${ }^{*}$ or $1_{s}^{\prime}$-inch stainless steel rods were pressed into the drill holes. The rivets were bonded with an epoxy resin glue to the plastic knobs and to the brass knobs with solder. When completed the spokes protruded 3/32 inch beyond the rim of the knob. Knobs of less than ${ }_{4}^{\prime}$ inch in diameter were studded with four

"Dot rivets \#4827. United-Carr Co. Ltd., Montreal, Quebec. 
spokes at 90-degree intervals, and larger knobs with six spokes at 60-degree intervals. When a machine had fine and coarse oxygen flow controls, both were altered.

These modified knobs provided a distinctive tactile sensation without interfering with rapid manipulation.

Forty-three machines manufactured by seven different companies were altered at a cost of less than $\$ 1.05$ per machine. An example of the completed modification is presented in Figure 3.

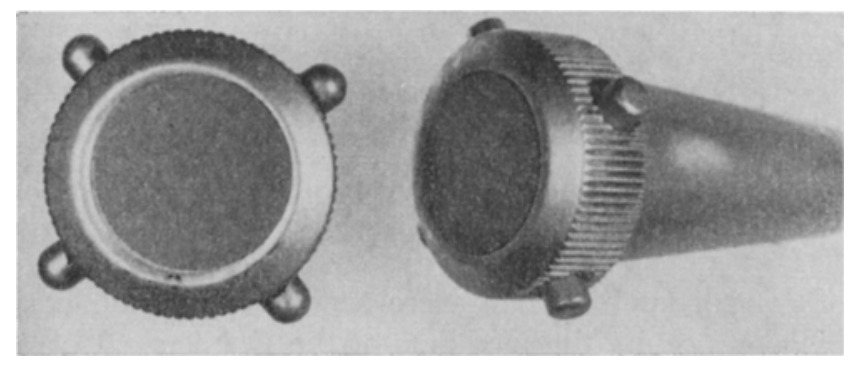

FIGURE 3. Photograph of modified oxygen flowmeter knob.

\section{Assessment of Results}

The anaesthetists were asked their opinion of the altered controls after using them for two months. Their reports were universally favourable. They found the controls easy to operate and appreciated the confidence which touch confirmation provided. They suggested that this modification of the oxygen flow control should be recommended to committees on standardization of anaesthetic apparatus.

\section{SUMMARY}

Touch identification of oxygen flow control knobs improves the operating safety of anaesthetic machines by increasing the ability of the anaesthetist to distinguish the oxygen flowmeter from the other flowmeters in the rotameter head. The Hospital for Sick Children, Toronto, employs spoked knobs which are easily and inexpensively produced, for all anaesthetic machines.

\section{RÉSUMÉ}

Les manettes de contrôle du courant d'oxygène de la plupart des machines à anesthésie sont uniformes aussi bien en ce qui concerne la dimension qu'en ce qui concerne la forme. A cause précisément de cette uniformité, l'anesthésiste est en imminence perpétuelle d'exposer son malade à des concentrations hypoxiques d'oxygène à cause de possibilités d'erreur dans le choix des gaz. Avec des appareils auxquels l'anesthésiste n'est pas habitué, cette erreur a été commise au cours de la réanimation et au cours de l'anesthésie.

Depuis que Eger a démontré que le rotamètre a oxygène devrait être placé le plus près de la sortie de la chambre de mélange, un nombre toujours croissant 
de manufacturiers déplacent la manette de contrôle du courant d'oxygène à un endroit inhabituel.

Le danger d'une identification inadéquate de la manette de contrôle du courant d'oxygène a été évité en mettant à point une manette distincte pour le contrôle du courant d'oxygène; cette manette est adaptable à toutes les machines à anesthésie.

Après avoir évalué plusieurs modèles de manette, les anesthésistes de l'hôpital des "Enfants Malades" de Toronto, ont arrêté leur choix sur une modification de manette d'où des épines de $1 / 3$ de pouce en acier inoxydable de $3 / 32$ de pouce à la périphérie de la manette à la distance de 90 ou 60 degrés selon la dimension de la manette.

Tout en utilisant les manettes de contrôle existant actuellement sur les machines à gaz, les altérations ont été faciles et peu coûteuses et, cela, pour toutes les sortes de machines à anesthésie.

Les contrôles modifiés ont été faciles à manipuler et ont procuré une confiance additionnelle dans le choix adéquat des gaz par l'identification au toucher du courant d'oxygène.

\section{ACKNOWLEDGMENTS}

I would like to thank Dr. A. W. Conn and all members of The Department of Anaesthesia, The Hospital for Sick Children, Toronto, for their support of this project. I am indebted to the staff of The Prosthetics Shop for preparing the modifications so skillfully and inexpensively.

\section{REFERENCES}

1. Cons, A. W. Personal communication.

2. Bishop, C.; Levick, C. H.; \& Hodrson, C. A design fault in the Boyle apparatus. (Correspondence) Brit. J. Anaesth. 39: 908 ( I967)

3. Eger, E. I.; Hylton, R. R.; Irwin, R. H.; \& Guadagni, N. Anaesthetic flow meter sequence - A cause for hypoxia. Anesthesiology. 24: 396 (1963).

4. KATZ, D. Recurring cyanosis of intermittent mechanical origin in anaesthetized patients. Anesth. \& Analg. 47: 233 (1968).

5. KATz, D. Increasing the safety of anaesthesia machines. I. Further modification of the Draeger machine. II. Consideration for the standardization of certain basic components. Anesth. \& Analg. 48: 242 ( 1969). 